\title{
Niepowtarzalne doświadczenie świata (O Stanisławie Jaworskim - wspomnienia i lektury)
}

\begin{abstract}
Ligęza Wojciech, Niepowtarzalne doświadczenie świata (O Stanisławie Jaworskim wspomnienia i lektury) [An inimitable experience of the world (On Stanisław Jaworski - a variety of recollections and readings)]. „Przestrzenie Teorii” 29. Poznań 2018, Adam Mickiewicz University Press, pp. 387-397. ISSN 1644-6763. DOI 10.14746/pt.2018.29.19.

This article is composed of three main parts: the first part briefly presents Prof. Jaworski's professional and creative accomplishments, the second part provides a description of the most important research questions addressed by Prof. Jaworski in his scholarly work, while the last section of the article is devoted to personal recollections by the present writer, highlighting the profiles and roles of Professor Jaworski as a lecturer, scholar, intellectual, editor, science organiser and discourse partner. Stanisław Jaworski was a prominent expert in the Kraków Avantgarde group and the subsequent history of this avant-garde movement in Polish poetry in Poland as well as on changes and literary recurrences in modern Polish and European literature. His literary research techniques include a comparative perspective as an important element, whereas interpretations of poems still play a substantial part. Prof. Jaworski has written a groundbreaking work Piszę, więc jestem? [I write therefore I am?] introducing new ideas and methods in genetic criticism, the approach to the study of literature Prof. Jaworski adopted and developed. The present article identifies common ideas and ways of thinking in research and poetical creative work.
\end{abstract}

KEYWORDS: memoirs, theory of literature, avant-guard as the literary movement, history of science, poetry

Dokonania naukowe, jak również aktywność dydaktyczna profesora Stanisława Jaworskiego związane były z Uniwersytetem Jagiellońskim. Po ukończeniu studiów polonistycznych (UJ, 1956) przyszły badacz rozpoczał pracę w ówczesnej Katedrze Literatury Polskiej w Instytucie Filologii Polskiej przy ul. Gołębiej 20. Tam Stanisław Jaworski doktoryzował się w roku 1965, przedstawiając napisana pod kierunkiem profesora Henryka Markiewicza rozprawę Tadeusz Peiper - pisarz i teoretyk, habilitował się zaś na podstawie książki Między awangarda a nadrealizmem. Gtówne kierunki przemian poezji polskiej w latach trzydziestych na tle europejskim (1976). W 1987 roku został profesorem. Profesor Jaworski pełnił szereg odpowiedzialnych funkcji: był prodziekanem Wydziału Filologicznego UJ (1975-1978), a następnie dziekanem (1978-1981), kierował z czasem przekształconym w Katedrę Zakładem Teorii Literatury i Poetyki Historycznej (1976-1979; 1993-1996), natomiast w latach 1984-1988 sprawował obo- 
wiązki wicedyrektora Instytutu Filologii Polskiej UJ. Łącząc doświadczenia krytyka i badacza literatury oraz poety, prowadził zajęcia w Szkole Literacko-Artystycznej UJ przygotowujacej adeptów sztuki słowa.

Stanisław Jaworski gościnnie wykładał na uniwersytecie w Grenoble (1966-1969), a później - w różnych latach - w Nancy oraz Lyonie. Pobyty te zaowocowały znakomita znajomością francuskich prac teoretycznoliterackich oraz francuskiej literatury pięknej, co spożytkował w serii swoich inspirujących tekstów. Wskazać też należy związek z inną uczelnią mianowicie z Państwowa Wyższą Szkołą Zawodową w Tarnowie, gdzie w latach 1998-2014 - poza obowiazkami dydaktycznymi - profesor Jaworski pełnił funkcję kierownika zespołu badawczego specjalizującego się w literaturze nowej i najnowszej.

Ogłaszane publikacje książkowe wyznaczają szerokie spectrum literaturoznawczych zainteresowań Stanisława Jaworskiego, a jednocześnie ukazują konsekwencję w postępowaniu badawczym, czyli wierność wiodącym tematom. Rygor naukowy i pasja krytyczna uzupełniają się nawzajem. Oto tytuły książek Jaworskiego: U podstaw awangardy. Tadeusz Peiper, pisarz i teoretyk (1968, II uzupełnione wydanie 1980), Między awangardq a nadrealizmem. Główne kierunki przemian poezji polskiej w latach trzydziestych na tle europejskim (1976), Odnajdywanie świata (1984), Awangarda (z antologia, Biblioteka Polonistyki), Piszę, więc jestem. O procesie twórczym $w$ literaturze (1993), Zakręty i przełomy (2002) oraz Maski, gesty, stowa (2014). Pamiętać należy o dwóch często wznawianych pozycjach słownikowych czy też wariantach dostosowanych do poziomu studiujących (Stownik szkolny. Terminy literackie, 1990 i następne edycje oraz Podręczny słownik terminów literackich, 2000, 2007). Badacz redagował też tomy zbiorowe, takie jak Studia o narracji (1982), Światy nowej prozy (2001) czy niedawno Zdzistaw Beksiński a kultura wspótczesna (2014). Rozprawy i recenzje - szczególnie w ostatnich latach - Stanisław Jaworski publikował w „Ruchu Literackim” oraz „Przestrzeniach Teorii”.

Wśród zasług Profesora istotne miejsce zajmuje udział w pracach zespołu redakcyjnego miesięcznika „Ruch Literacki”, w tym sprawowanie funkcji redaktora naczelnego tego periodyku (1984-1989). Wybitny znawca twórczości Tadeusza Peipera - przez ponad dwie dekady, od roku 1972, kiedy ukazał się w krakowskim Wydawnictwie Literackim tom Tędy i Nowe usta, był naukowym redaktorem pism zebranych papieża polskiej awangardy. Przygotowywał przedmowy, komentarze, noty, pamiętając o tym, że dokonał się istotny zwrot w świadomości artystycznej nowoczesnej poezji. Prawdziwy podziw budzi w tych komentarzach sztuka syntezy i sztuka panoramy literackiej. Wcale nie marginalna pochodna jest popularyzacja w wysokim stylu, czyli opatrzone wstępem i opracowane przez profesora 
Jaworskiego wydanie Pism wybranych Tadeusza Peipera w „Bibliotece Narodowej” (1979, I, 235). Ponadto Profesor przybliżył czytelnikom nieczęsto wznawiane w Polsce po drugiej wojnie światowej poezje z kręgu awangardy, uczestnicząc w wydaniach, redagując, pisząc przedmowy do wyborów wierszy Jana Brzękowskiego, Jalu Kurka, Jerzego Pleśniarowicza, Mariana Jachimowicza.

Kolejną przestrzenią kultury, w której Stanisław Jaworski się realizował, było życie literackie - przede wszystkim Krakowa. W tym mieście należał do grona założycieli oraz redaktorów „odwilżowego” pisma grafików i literatów „Czarno na Białym”, przemianowanego na „Zebrę”, które, co prawda, wychodziło przez półtora roku, ale odegrało ważną rolę w czasach popaździernikowego przełomu. W tym otwartym na nowe nurty w sztuce periodyku Stanisław Jaworski zamieszczał utwory liryczne oraz redagował dział poezji. Jako poeta i jako krytyk ogłaszał swoje teksty między innymi w „Lewarach”, „Poglądach”, „Wektorze”, „Życiu Literackim”. Te próby literackie docenili Wisława Szymborska i Karl Dedecius. W późniejszym okresie, kiedy rola uczonego wybiła się na plan pierwszy, Jaworski nie publikował wierszy, ale nie znaczy to, że zarzucił czynne uprawianie sztuki słowa.

Jako rodzaj kody poetyckiej traktować należy opublikowanie w roku 2018 w serii „Krakowska Biblioteka Stowarzyszenia Pisarzy Polskich” tomu zatytułowanego Którędy, który zawiera utwory rozproszone w prasie oraz inedita - od debiutu po lata dojrzałe. W kilkuzdaniowym wstępie do wymienionego zbioru Profesor napisał, iż „każdy wiersz to jakby spotkanie

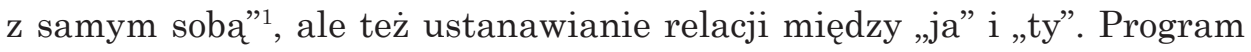
niedaleko odbiega od myśli przewodnich jego prac naukowych, w których powracają w rozmaitych konfiguracjach kategorie spotkania i kształtowania podmiotu.

W 2010 roku ukazała się książka Od polityki do poetyki. Prace ofiarowane Stanisławowi Jaworskiemu (redakcja: Cezary Zalewski, wstęp: Anna Burzyńska). W Collegium Maius - 10 października 2016 roku - odbyła się uroczystość odnowienia doktoratu profesora Stanisława Jaworskiego, po pół wieku od obrony dysertacji o twórczości Tadeusza Peipera. 23 stycznia 2018 roku wieczór w Stowarzyszeniu Pisarzy Polskich w Krakowie przy ulicy Kanoniczej 7 poświęcony był promocji tomu wierszy Którędy. W przeddzień tego spotkania z publicznością Profesor zachorował, przewieziony został do szpitala, nie mógł więc uczestniczyć w prezentacji tak przez Niego oczekiwanej książki. Choroba okazała się śmiertelna, Stanisław Jaworski zmarł 15 lutego, pochowany został na cmentarzu Rakowickim w Krakowie.

${ }^{1}$ S. Jaworski, Którędy, posłowie E. Zechenter-Spławińska, Kraków 2018, s. 5. 
W twórczości naukowej Stanisława Jaworskiego kilka wątków wybija się na plan pierwszy. Do nich należą: historia, teoria i praktyka twórcza polskiej awangardy poetyckiej dwudziestolecia międzywojennego, europejskie konteksty prądów i nurtów w nowoczesnej polskiej literaturze, dalsza historia awangardy wraz z modulacjami, przemianami, przełomami, kryzysami, dzieje świadomości metaliterackiej odzwierciedlone w wystapieniach programowych, wreszcie zagadnienia procesu pisania, które wyprzedzały popularna obecnie krytykę genetyczna.

Ze wskazaną sekwencją tematów badawczych łączą się liczne uzupełnienia, a także ekskursy na przyległe pola refleksji, takie jak nowe koncepcje osobowości, konstrukcje podmiotu literackiego - rozszczepionego, zawieszonego między ,ja” i „nie-ja”, co wiąże się z problematyką tożsamości w nowej liryce. Wśród eksplorowanych tematów ważne miejsce zajmuja między innymi zagadnienia wizyjności oraz obrazu, nowoczesne wcielenia mitu, pojmowanie sztuki literackiej nie jako skończonego dzieła, lecz jako dążenia, aktu pisarskiego „w drodze”. Wskażmy jeszcze sylwetki poetów minores międzywojnia (przykładem niech będzie przypomnienie Mili Elinówny), rozpoznania ważnych punktów myślowych i formalnych czytanych w oryginale powieści francuskich - Jeana Giono, Juliena Greena, André Malraux, Allaina Robbe-Grilleta, a także kwestie autobiografizmu w prozie polskiej końca wieku XX. Oczywiście ten wykaz musi pozostać szkicowy.

Profesor Jaworski wypowiadał się w wielu formach - od monografii pisarza w książce o Tadeuszu Peiperze, od studiów na jeden temat, integralnych, dopełniających się nawzajem, a zatem taką publikację nazwać można „monografią otwartą, oczekująca na nowe ustalenia (,Piszę, więc jestem”), po zbiory szkiców dotyczących zjawisk i nazwisk literackich, usytuowanych jeszcze w głównym kręgu zainteresowań autora, lecz wprowadzających nowy materiał eksplikacji, gdyż Jaworski wciąż precyzował swą myśl i dołączał nowe koncepty lektury (Odnajdywanie świata; Zakręty i przełomy; Maski, gesty, stowa). W szkicach krytycznych do perfekcji opanowana została poetyka portretu literackiego.

Narracje historycznoliterackie spotykają się tutaj z odkrywczymi interpretacjami. Dość tu wymienić jako przykłady odczytania Strefy Apollinaire'a, Tramwaju Ważyka, Przedświtu Józefa Czechowicza (Między awangarda a nadrealizmem), Spojrzenia Krzysztofa Kamila Baczyńskiego (Zakręty i przełomy), a także lektury utworów Lechonia, Miłosza, Szymborskiej. Często funkcję „koła zamachowego” ujęć syntetycznych spełnia interpretacja jako punkt wyjścia. Tak dzieje się na przykład w szkicach o Jalu Kurku, Marianie Czuchnowskim, Lechu Piwowarze (Odnajdywanie świata), Zbi- 
gniewie Herbercie (Zakręty i przełomy). Stanisława Jaworskiego interesowała „poezja wielu racji”, wielu punktów widzenia, starająca się uchwycić „ludzki byt w jego jednostkowej niepowtarzalności”, przeciwstawiać się utracie tożsamości, odrzucać kuszenia chaosem.

Wszechstronna erudycja, imponująca pod względem rozległości i różnorodności, jak to już zostało zaznaczone, rozszerzająca horyzont wiedzy o definitywne rozpoznania, o nowe źródła, o nieznane w Polsce prace w języ$\mathrm{ku}$ francuskim. Ślady wielotorowych lektur w tym przypadku nigdy nie sa ornamentem, nie mają nic wspólnego z encyklopedycznymi wypisami, lecz zostają ściśle sfunkcjonalizowane, stanowią raczej wskazany czytelnikowi trop poszukiwań czy też skromne z pozoru podpowiedzi bibliograficzne. Ujmujący jest lakonizm autora, gdyż książki Stanisława Jaworskiego nie osiągają dużej liczby stron, przeciwnie, mamy tu do czynienia z wypowiedziami syntetycznymi, często skrótowymi, lecz gęstymi od znaczeń. Myśl własna, porządkując inne głosy, dominuje nad przytaczanymi sądami. Prawie zbędna wydaje się uwaga, że literaturoznawca doby obecnej, zmuszony do gonitwy za punktami, podlegający uporczywym ocenom, postapiłby inaczej, czyli z biblioteki tekstów teoretycznych, kultywując manierę żmudnego referowania, ułożyłby opasłe tomy, a rzucane mimochodem informacje rozmnożyłby w osobne artykuły. Znamienne jest zdanie ze szkicu poświęconego Kwestii gustu Adama Ważyka: „I tylko ogromnej kulturze eseistycznej autora zawdzięczamy, iż ta summa mieści się na 200 stronach, zamiast rozlewać się na całe ich setki” 4 . Przytoczony fragment można uznać za ważny wyznacznik postawy pisarskiej Profesora.

Lakoniczność, o której mowa, przejawia się w porządku enumeracyjnym wykładu. Tezy zostaja tutaj od razu wyjawione, a rozwój wykładu prowadzi często od przypadków tekstowych tematycznie oraz genologicznie wyrazistych - do sylwów i hybryd, zmieszania jakości, które dezorientują czytelnika i wprowadzają możliwość kilku na raz lektur alternatywnych. Tak zbudowane zostaja rozprawy Maski i twarze. Proza polska lat 90-tych $i$ autobiografizm oraz $O$ pożytkach wtasnych ptynacych $z$ pisania (w tomie Zakręty i przełomy). Co charakterystyczne, autor wprowadza zestawienia nieoczywiste, zapoznajemy się bowiem ze strategiami autobiograficznymi - od Zapamiętanego Kazimierza Brandysa i Pamfletu na samego siebie Tadeusza Konwickiego do Szczura Andrzeja Zaniewskiego, My zdies emigranty Manueli Gretkowskiej oraz powieści Biały kruk Andrzeja Stasiuka. Natomiast kwestia „kompozycji istnienia” w aktach pisarskich, czyli „kon-

${ }^{2}$ Tenże, Poeta: malarz czy muzyk?, [w:] tegoż, Odnajdywanie świata, Kraków-Wrocław 1984, s. 121.

${ }^{3}$ Tamże, s. $123-124$.

${ }^{4}$ Tenże, Lektury Albina, [w:] tegoż, Odnajdywanie świata..., s. 19. 
struowania wizji własnego bytu" ${ }^{\text {" }}$ rozpatrywana jest w dość zaskakującej sekwencji: Dzienniki czasu wojny 1939-1944 Nałkowskiej, Kon Pana Boga Dichtera, Mdłości Sartre'a, Niebieska menażeria Filipiak oraz Upadek Alberta Camusa.

W przywoływanych rozważaniach widoczna staje się pamięć o formach wcześniejszych, o ich postaciach oraz znaczeniu, jak również wyraźnie zaznaczona zostaje perspektywa komparatystyczna. Przy czym mocne podstawy porównania nie koliduja wcale z otwarciem nowego horyzontu, z tropami lektury, o których dotąd nie mieliśmy pojęcia. Rzeczowość i mnogość konkretów tekstowych, nieprzekształcających się w trudny do przebycia labirynt, to bez wątpienia mocna strona twórczości naukowej Stanisława Jaworskiego. Jednak na przeciwległym biegunie usytuować należy intuicję oraz imaginację. Deszyfrowanie sensów utworu według tego badacza jest spotkaniem wyobraźni pisarza z wyobraźnią czytelnika. Strona odbiorcy staje się równouprawnionym przedmiotem namysłu.

Chociaż Jaworski unika uwodzenia efektami stylistycznymi (elegancja stylu nie narzuca się w sposób ostentacyjny), to czasami rozważania zamyka mocna pointa-konkluzja (na przykład cytat o sile aforyzmu) lub - częściej rytm pytań, które tylko po części znalazły odpowiedzi, ponieważ wchodzą one w sferę niewiadomego i łączą się z prognozującymi rozważaniami krytyka. Na przykład: „Pisarz projektuje siebie w porozumieniu i dystansie do własnych tekstów i do Innych”; „Autor proponuje określoną grę, czytelnik [...] stara się przeniknać nie tylko zamiary autora, ale także jego nieuświadomione intencje. Odkryć, co kryje się za milczeniem pisarza. Ale co kryje się za milczeniem badacza?"

Naukowe wyznaczniki wykładu w tekstach Stanisława Jaworskiego graniczą ze stylem eseistycznym. Szczególnie jest to widoczne w zbiorze „Piszę, więc jestem”, w którym uczony rozluźnia rygory prac akademickich, wprowadzając dialog między własnym rozumowaniem a przytaczanymi krótkimi fragmentami, nieraz pojedynczymi frazami z cudzych pism literackich i krytycznych, stosuje retorykę pytań, odsłania niepewność poznawcza, eksponuje znaczenia nierozstrzygalne, jak w zdaniach: „Dzieło literackie nie jest, a w każdym razie nie musi być, wyznaniem, relacja o tym, co zdarzyło się naprawdę. Może być - jest? - w tym samym stopniu projektem lub negatywem”; „Rola dziennika może bowiem polegać (polega?) także na stwarzaniu psychicznego alibi, na tłumaczeniu się przed samym sobą jeśli nawet nie przed czytelnikiem".

${ }^{5}$ Tenże, O pożytkach wtasnych ptynacych z pisania, [w:] tegoż, Zakręty i przełomy. Studia o literaturze XX wieku, Kraków 2003, s. 186.

${ }^{6}$ Tenże, Rozmowa z samym soba (do potomności). „Przestrzenie Teorii” 2008, nr 9, s. 91.

${ }^{7}$ Tenże, Mówić o sobie i milczeć, [w:] tegoż, Zakręty i przełomy..., s. 183. 
$\mathrm{W}$ „Pisze, więc jestem” znajdziemy sporo zdań kwestionujących pewniki bądź rejestrujących szczególne przypadki tekstowe, pojedyncze, swoiste, sprzeciwiające się normom. Istota wyłaniania się tekstu z psychologiczno-kulturowego niebytu, jak też próba opisania momentu, kiedy dzieło kiełkuje w świadomości, ale kształt artystyczny nie jest gotowy, albo (innymi słowy) zamiar uchwycenia tajemnicy aktu twórczego wymaga innego podejścia niż standardowe procedury polonistyczne. Najlepiej być pisarzem, by zbliżyć się fascynujących przedsłownych światów doświadczenia i pragnienia, kształtowania egzystencji i walki z niebytem. Oto więc literaturoznawstwo w jakimś swym zakresie staje się literatura. Jak przeczytamy w „Piszę, więc jestem”:

Niektórzy uznaja, że pomiędzy kreatywnością a twórczością nie ma różnicy natury, lecz jedynie stopnia. Panuje nadto przekonanie, że praca artysty i uczonego nie różnią się; [...] w twórczości naukowej podobną rolę odgrywają takie techniki, jak szukanie rozwiązań niebanalnych, przeniesienie zwykłego w niezwykłe i odwrotnie, działanie przez analogię. Mówi się, że wytwarzanie pomysłów zachodzi w nauce podobnie jak w sztuce ${ }^{8}$.

Cytowane próbki potwierdzają takie stanowisko. Język giętki, obrazowy, potoczny, a zarazem elegancki, jak wskazuja wypisy, wcale nie kłóci $\mathrm{z}$ wymogami naukowego dyskursu.

Profesor Stanisław Jaworski był znakomitym dydaktykiem. Miałem sposobność uczęszczać na jego wykłady z teorii literatury (w roku akademickim 1972-1973). Te zajęcia wyróżniały się wyjątkową precyzją przedstawiania poszczególnych zagadnień oraz jasnością myśli. Każdy z wykładów tworzył zamkniętą całość. Języki teorii układały się w przekonujące sekwencje, tworząc systematycznie przyrastającą całość. Znikało wrażenie hermetyczności, teoria literatury przestawała być domena dla wajemniczonych.

Profesor do minimum sprowadzał elementy teatru, od których żaden wykład nie może być do końca wolny. Dyscyplina słowa wprowadzającego od razu w meritum problematyki odsuwała na plan dalszy retorykę kwiecista - w innych przypadkach służąca popisowi oratorskiemu. A jednak w modulowaniu głosu (bez przesadnych efektów), w rytmie zdania, w rozkładzie pauz, w małych dawkach milczenia wyczuwało się estetyczny wymiar wypowiedzi. Jakby za wywodami głoszonymi ku pożytkowi dydaktycznemu ukrywał się artysta, dla którego ekspresja osobowości nie pozostawała sprawą obojętna. Jak rzecz rozumiem, Profesor nie chciał być jedynie medium nauki. Zgodnie ze strategiami obowiązującymi na uczelniach zachodnich

${ }^{8}$ Tenże, „Piszę więc jestem”. O procesie twórczym w literaturze, Kraków 1993, s. 35. 
rodzajem intermediów czy momentów wytchnienia stawały się oszczędnie odmierzane barwne anegdoty. Ujmujące były dyskretne sygnały autoironii oddalające na chwilę role uczonego i wykładowcy.

Ćwiczenia z teorii literatury prowadzone przez Stanisława Jaworskiego należały do najlepszych, najbardziej inspirujących, a trzeba o tym pamiętać, iż w Instytucie Filologii Polskiej przy Gołębiej 20 w tamtych latach studenci mogli obcować na co dzień z wybitnymi indywidualnościami. Te zajęcia wyróżniały się starannie obmyślonym programem, nastawione były na dyskusję, wyzwalały rozwój myślenia. Czytaliśmy prace z wersologii i kompozycji tekstu literackiego, zapoznawaliśmy się z formalizmem rosyjskim, przyswajaliśmy rozprawy strukturalistyczne - światowe i polskie, teraz wypełniające klasyczny kanon, staraliśmy się wniknąć w arkana propozycji semiotycznych.

Francuska myśl teoretycznoliteracka Barthesa, Kristevej oraz innych zajmowała uprzywilejowana pozycję. Stanisław Jaworski prace z tamtego kręgu poznał z „pierwszej ręki”. Mit i znak Rolanda Barthesa (edycja polska, 1970) był książka omawianą w czasie tych ćwiczeń, a rozprawy Mit dzisiaj i Mitologie codzienne wprowadziły prawdziwą nowość, rewidowały utrwalone sposoby czytania, wykraczały poza obszar tekstów literackich. Nie zabrakło też konstruktywnego wprowadzenia do fenomenologii wyobraźni poetyckiej Gastona Bachelarda.

Opisuję tylko niewielki wycinek edukacyjnej przeszłości, subiektywnie odczuwany, przesączony przez filtr wspomnień i z tego powodu zachowane zostaja tylko pewne epizody. Oto dwa przykłady: interpretacja wiersza Wieczór Juliana Przybosia ukazywała reguły czytania subtelnych szyfrów liryki, w których ekspresja uczuć ulegała obiektywizacji oraz zapośredniczeniu, gdyż rzutowana była na gasnący w półmroku krajobraz miasta. Nade wszystko jednak liczą się tutaj konstrukcja podwojonego podmiotu oraz nakładanie się na siebie „czasu wspominanego i czasu wspominania”. Studiowanie zaś fragmentów Ulissesa Joyce'a połączone zostało z próbami quasi-literackimi, gdyż każdy z uczestników zajęć miał napisać tekst technika strumienia świadomości. Poprzez pastisz wchodzący w boczne rozgałęzienie krytyki odsłaniały się reguły takiego sposobu narracji. W tym miejscu można by mówić nie tylko o podglądaniu warsztatu artystycznego, lecz o czynnej imitacji, o bardzo pożytecznej wprawce. Fenomen pisania, przezwyciężania momentu „zero”, kiedy biała kartka nie zapełniła się znakami, od dawna Profesora interesował. Dodać też trzeba, że taka metoda

${ }^{9}$ Tenże, Poezja-dynamika osobowości, [w:] tegoż, Między awangarda a nadrealizmem. Główne kierunki przemian w poezji polskiej w latach trzydziestych na tle europejskim, Kraków 1976, s. 153. (Interpretacja wiersza Wieczór s. 150-156). Zob. także: tegoż, „Piszę, więc jestem”..., s. 96-102. 
ćwiczeń pojawiła się przed zajęciami z creative writing (a pionierską rolę w tym zakresie odegrało Studium Literacko-Artystyczne UJ).

Po wielu latach, po spotkaniach na korytarzach krakowskiej polonistyki, bądź na Radzie Wydziału, po rozmowach i małych narracjach, zawsze ciekawie przez Profesora konstruowanych, wywiązała się ściślejsza współpraca. Otóż znalazłem się w radzie naukowej konferencji „Przed-tekstowy świat. Archiwa, bruliony, rękopisy" zorganizowanej przez IBL PAN oraz Wydział Polonistyki UJ (2016) i mogę świadczyć, iż przy kwalifikacji nadesłanych prac ocena Stanisława Jaworskiego każdorazowo była celna, sprawiedliwa, w kilku zdaniach rozpoznająca wartość badawczej propozycji. Jego głos miał znaczenie największe w eksplikacjach idei sympozjum, jak też w układaniu programu. Podobnie określić należy wystapienie Profesora podczas rozpoczęcia konferencji. Dodajmy jeszcze, że polska odmiana krytyki genetycznej wiele zawdzięcza książce „Piszę więc jestem”- bez wątpienia prekursorskiej.

Szczególnym doświadczeniem były liczne kontakty związane z przygotowaniem tomu wierszy Stanisława Jaworskiego Którędy do wydania w serii „Krakowska Biblioteka Stowarzyszenia Pisarzy Polskich”, którą redaguję wspólnie z profesor Gabrielą Matuszek-Stec. Początkowo nie byliśmy przekonani o zasadności drukowania juweniliów, ale to był błąd z naszej strony, ponieważ nie rozpoznaliśmy w pełni zamysłu, żeby autobiografia uczuć ujawniła się we wszystkich zmieniających się postaciach - od czasów życiowego terminowania po lata dojrzałe. Za moją radą Autor najwcześniejsze utwory zamieścił na końcu zbioru, pod wspólnym tytułem wczesne.

Wielokrotnie w pismach krytycznych Stanisława Jaworskiego przeczytamy o lęku przed psychicznym obnażeniem, o maskach i rolach, społecznych ograniczeniach jednostki, a równocześnie o egzystencjalistycznej koncepcji człowieka oraz o potrzebie formowania samego siebie. W skrócie rzecz wykłada się następująco: to, co jednostkowe, prowadzi do „niepowtarzalnego doświadczenia świata"10. Artystyczny wymiar wypowiedzi w liryce skłania do poszerzenia obszaru samoobserwacji. Nie znaczy to jednak, że autor Którędy (w tytule $\mathrm{z}$ ducha awangardy już zawiera się podążania w wybranym kierunku) w poszukiwaniu realnego świata, a także w aktach autokreacji wybiera prostoduszna szczerość. Wsłuchując się w głosy wielorakiej rzeczywistości, starając się odczytać paradoksalną mowę milczenia, rekonstruując dawne relacje i rozmowy, przenikając w sferę snu, zaznacza dystans wobec poezji konfesyjnej, w sposób wyrafinowany posługuje się ironia, posiłkuje się subtelnie wyrażonym żartem.

Co znamienne, w omawianych wierszach opracowane zostają doświadczenia literaturoznawcy oraz dydaktyka. W scenerii zajęć polonistycznych

${ }^{10}$ Tenże, Odnajdywanie świata, Kraków-Wrocław 1984, s. 126. 
umieszczona zostaje refleksja o oswajaniu własnego losu za pośrednictwem lektury cudzych tekstów oraz rozmyślania o nieskuteczności takiej terapii (***pójdziesz w przeciwna stronę). Mikrostudium o rozdwojeniu na podmiot autorski w wierszu i „podmiot ludzki” zanurzony w egzystencji odsłania nieuniknioną obcość (twoja tożsamość), zdrada autentyku przez konwencję ogranicza pole manewru, ponieważ „układanie dramatu” jest czymś innym, niż rzetelne (niewypowiedziane) świadectwo o prawdziwym życiu, którego i tak nie skoryguja gry tekstowe.

Pisanie zyskuje szczególny wymiar, gdyż zdobyć należy nowe istnienie, przebić się ku prawdzie o sobie, sprzeciwiać się temu, co zastane, utwierdzone i potwierdzone. Topos pomieszania niemożliwego z możliwym, kiedy ryzyko zapisu zostaje podjęte, przewija się w liryce, w esejach, w rozprawach Stanisława Jaworskiego. A zatem uczony wspiera poetę swym wtajemniczeniem, poeta spogląda na uczonego i w jakiejś mierze demaskuje jego uzurpacje. Tak Elżbieta Zechenter-Spławińska komentuje regułę oscylacji ról: „Trzeba jakiejś dozy szaleństwa, trzeba odwagi, żeby - będąc znakomitym profesorem, mającym na swym koncie świetne polonistyczne publikacje zdecydować się na druk tej książki: poetyckiego pamiętnika, prowadzonego od lat studenckich do chwili obecnej"11.

Rozmowy poświęcone redagowanym tekstom i wyłanianiu się kształtu kompozycyjnego zbioru były dla mnie ze wszech miar inspirujące. Każdą z propozycji poprawek Profesor dokładnie rozważał, lecz często, choć nie zawsze, bronił wersji pierwotnych. Każdy drobiazg musiał zostać przedyskutowany (czy zaimek może znaleźć się na końcu wersu, czy w staroświeckim patefonie zmienia się igłę czy igły). Zdawałoby się, proste sformułowania w tych lirykach wynikały ze skomplikowanych motywacji sytuacyjno-psychologicznych, zawsze wytłumaczonych. Trudno się zresztą dziwić, że u teoretyka literatury świadomość warsztatu była tak rozwinięta. Żartobliwość intencji i delikatnie zaznaczona parodystyczność wypowiedzi niekiedy trudna była od razu do uchwycenia, wówczas Stanisław Jaworski używał wdzięcznej frazy: „to są wiersze hecne”. Pracę redakcyjną chętnie uznałbym za kontynuację dawnych ćwiczeń z teorii literatury - w zupełnie zmienionych okolicznościach.

Stanisław Jaworski nie był rozmówcą łatwym. Nie interesowały Go ani nieistotne tematy ulicy, ani suche wymiany polonistycznych uwag fachowych. Sztampa każdorazowo musiała zostać przełamana. Należało uważnie śledzić tok rozumowania, dygresyjny, rozgałęziony, zwracać uwagę na cienkie ironie oraz przemycane skojarzenia erudycyjne. Delikatność w obyciu odpowiadała delikatności słowa, jakby wycofanego, zawieszającego ostre

${ }^{11}$ E. Zechenter-Spławińska, Drugie życie wiersza, [w:] S. Jaworski, Którędy..., s. 85. 
konkluzje. Powrót do przerwanego toku, bądź kolejne nawiązanie sygnalizowało charakterystyczne dla języka Profesora słówko „właśnie”. W ostatnim czasie pojawiały się wattki wspomnieniowe, opowieści o pracy nad Peiperem, o funkcjach uniwersyteckich, środowisku, o tak zwanym życiu literackim, o Francji - pełne świetnych spostrzeżeń, warte osobnego spisania.

Profesor był osobą życzliwą ludziom, zawsze gotowy do wysłuchania z empatią swoich rozmówców. Stanisław Jaworski w ostatnich latach bywał na niemal wszystkich spotkaniach autorskich w Stowarzyszeniu Pisarzy Polskich, brał też udział w rozlicznych inicjatywach literackich i naukowych. Jego głos w dyskusjach wprowadzał nowe spojrzenie, nowe rozwiązania. Słuchaliśmy z uwaga...

Nad wydaniem tomu Którędy zawisło fatum. Najpierw zbyt długo przymierzałem się do lektury wierszy, później szlifowanie całości zabrało sporo czasu, drukarnia się spóźniła i pierwszy termin wieczoru autorskiego został odwołany. Drugie spotkanie w SPP na Kanoniczej, jak pisałem, odbyło się bez udziału Autora. Według relacji przyjaciół, którzy odwiedzali Profesora w szpitalu, zbiór został przez Niego zaakceptowany. W planach umieściliśmy powtórzenie w przyszłości tego wieczoru. Nie opuszcza mnie poczucie owego „za późno” i słabym pocieszeniem jest to, że nie potrafimy wejrzeć w przyszłość, nawet tę najbliższa.

Profesor zapadał na zdrowiu, miał kłopoty z równowaga, z chodzeniem, o czym mówił w autoironicznym dystansem. Jego wieloraka aktywność, jak teraz to widzę, była heroiczna, chodziło bowiem o to, żeby działać do końca, nie rezygnować, ofiarowując innym - na przekor słabościom ciała - swoją obecność, mądrość i wielki format intelektualny. Żegnamy literaturoznawcę, krytyka, poetę, wykładowcę, organizatora nauki, a nade wszystko człowieka mądrej rady, szerokich horyzontów myślowych, uroku osobistego, zalet towarzyskich. W jednym z wczesnych wierszy ${ }^{12}$, unikając wielkich słów, Stanisław Jaworski tak pisał o odchodzeniu:

zostawić wszystko jak się pozostawia

z nadejściem lata w szafie ciepłą odzież

w każdym ze śladów pozostawić siebie

${ }^{12}$ S. Jaworski, prosto przed siebie, [w:] tegoż, Którędy..., s. 81. 
